\title{
WYBRANE ASPEKTY POLITYKI MIGRACYJNEJ W ŚWIETLE BADAŃ NAD ARABSKĄ DIASPORĄ W POLSCE
}

\section{Wprowadzenie}

Od zarania państwowości na polskich ziemiach krzyżowały się różne narodowości ${ }^{1}$, zatem polska wielokulturowość ma bardzo długą historię ${ }^{2}$. Biorąc pod uwagę XX w., zwany „wiekiem migracji” ", Polska jeszcze w okresie międzywojennym była krajem wielokulturowym. Jej późniejsze losy sprawiły, że z kraju heterogenicznego wyznaniowo i etnicznie zmieniała się w państwo homogeniczne, z bezwzględną dominacją społeczeństwa przyjmującego. Mniejszości etniczne i religijne oraz liczba imigrantów stanowią w Polsce obecnie niewielki odsetek społeczeństwa, mimo że po transformacji ustrojowej oraz przystąpieniu Polski do Unii Europejskiej i systemu Schengen nastąpiło otwarcie granic. Paradoksalnie ww. wydarzenia wpłynęły bardziej na odpływ miejscowej ludności niż na napływ imigrantów - według danych GUS w końcu 2014 r. 2 mln 320 tys. Polaków przebywało za granicą ${ }^{4}$, natomiast według danych UDSC na początku stycznia 2015 r. ważne karty pobytu w Polsce, niezależnie od rodzaju zezwolenia, posiadało 175066 obcokrajowców ${ }^{5}$.

Polska jest zatem krajem emigracyjnym, a do imigracji polskie władze jak dotąd miały powierzchowny stosunek - były zainteresowane jedynie polityką migracyjną w kontekście kontroli granic czy dostępu imigrantów do rynku pracy. Politycy nie byli zainteresowani tematem integracji imigrantów w Polsce i nie widzieli potrzeby

1 Por. A. Chodubski, Mniejszości narodowe $w$ dziejach polskiej cywilizacji, w: A. Chodubski, Meandry cywilizacyjne, kwestie narodowościowe i polonijne, Wydawnictwo Adam Marszałek, Toruń 1996, s. 43-55.

2 A. Chodubski, Obraz imigracji w Polsce w latach dziewięćdziesiątych, w: Imigranci i społeczeństwa przyjmujace. Adaptacja? Integracja? Transformacja?, „Migracje i Społeczeństwo” 5, Wydawnictwo Neriton, Warszawa 2000, s. 212-215.

3 Por. S. Castles, M.J. Miller, The Age of Migration. International Population Movements in the Modern World, Guilford Press, New York 2003.

4 Informacja o rozmiarach i kierunkach emigracji z Polski w latach 2004-2014, GUS, Warszawa 2015, s. 2.

5 http://udsc.gov.pl/statystyki/raporty-okresowe/zestawienia-roczne/ [dostęp 24.01.2016]. 
aktywizacji tej grupy społeczeństwa. Jednak coraz częściej prowadzi się konsultacje z tzw. trzecim sektorem, czyli organizacjami pozarządowymi, w tym imigranckimi ${ }^{6}$. W efekcie trwają już prace nad ustaleniem formalnej polityki migracyjnej, a Polska jest $w$ trakcie procesu transformacji z kraju tradycyjnie emigracyjnego w kraj także przyjmujący imigrantów ${ }^{7}$.

Obecnie polityka migracyjna w Polsce jest rozumiana jako całokształt zasad i działań państwa w odniesieniu do migracji zagranicznych z/i do Polski (emigracji i imigracji $)^{8}$, jednak na potrzeby badań diaspory arabskiej w Polsce, z racji badanej grupy docelowej, zastosowano zawężoną definicję tej polityki, utożsamianą przede wszystkim $\mathrm{z}$ aktywnym zarządzaniem procesami imigracyjnymi. W takim ujęciu polityka migracyjna to „zbiór zasad i działań podejmowanych przez organy państwa w stosunku do napływających i przebywających na jego terytorium cudzoziemców, przede wszystkim w odniesieniu do kontroli wjazdu (i wyjazdu), dostępu do rynku pracy oraz integracji ze społeczeństwem" ${ }^{\text {. }}$

\section{Cel artykułu}

Artykuł ten koncentruje się zatem na historii i ewolucji polityki migracyjnej w zakresie dotyczącym jedynie zjawiska imigracji, a zwłaszcza integracji obcokrajowców. Jego celem jest przedstawienie zagadnień powiązanych z obecną polityką migracyjną Polski w kontekście badań diaspory arabskiej w Polsce, w odniesieniu do aktualnie obowiązującego dokumentu pt. „Polityka migracyjna Polski - stan obecny i postulowane działania", który poddano analizie krytycznej. Należy przy tym podkreślić, iż część uwag i opinii badanych respondentów ma charakter uniwersalny, dotyczy wszystkich imigrantów w Polsce, nie tylko eksplorowanej społeczności. Dzięki temu stało się możliwe wypracowanie pewnych konkretnych innowacyjnych

6 P. Każmierkiewicz, J. Segeš-Frelak, Partycypacja publiczna i prawa polityczne obywateli państw trzecich na szczeblu krajowym i lokalnym, w: W poszukiwaniu nowych wzorów integracji cudzoziemców. Wybór tekstów polskiego forum integracyjnego, red. J. Segeš-Frelak, K. Grot, Fundacja Instytut Spraw Publicznych, Warszawa 2013, s. 33.

7 Ekspertyza podsumowująca doświadczenia teoretyczne i empiryczne nad społecznym i ekonomicznym wymiarem integracji. Moduł III. Integracja cudzoziemców w Polsce, Ośrodek Badań nad Migracjami WNE UW, Warszawa 2007, s. 5.

8 Założenia polityki ludnościowej Polski 2013. Projekt, Rządowa Rada Ludnościowa, Warszawa 2013, s. 177.

9 Założenia polityki ludnościowej Polski 2006, Raport Rządowej Rady Ludnościowej, Warszawa 2006, s. 3. 
rozwiązań - zaprezentowanych $\mathrm{w}$ tym artykule, $\mathrm{z}$ których skorzystać mogą polskie władze w celu efektywniejszego wykorzystania zjawiska imigracji.

Reprezentanci diaspory arabskiej byli jednymi z pierwszych cudzoziemców przybyłych do Polski przed 1989 r. po zakończeniu II wojny światowej - przyjeżdżali do Polski na studia w ramach bilateralnych umów pomiędzy Polską a krajami arabskimi o socjalistycznym rodowodzie. Przez ponad 45 lat życia w Polsce ${ }^{10}$ „polscy Arabowie" byli świadkami kolejnych etapów tworzenia polskiej polityki migracyjnej oraz podlegali stopniowo procesom integracyjnym.

\section{Informacja o przeprowadzonych badaniach}

Inspiracją do podjęcia tego tematu były odpowiedzi arabskich i polskich respondentów na pytania dotyczące polityki migracyjnej, integracji i zagadnień im pokrewnych (w tekście zaprezentowano przykładowe wypowiedzi uczestników badań). Dane empiryczne wykorzystane w artykule to wstępny efekt badań terenowych przeprowadzonych od maja 2013 do marca 2014 r. ${ }^{11}$ Badaniu głównemu poddano stu przedstawicieli diaspory arabskiej w Polsce i dla porównania stu Polaków, stosując m.in. metodę kuli śnieżnej jako technikę doboru próby ${ }^{12}$. Badanie przeprowadzono w dwunastu miastach Polski, w których znajdują się oddziały organizacji polsko-arabskich i są najliczniejsze lokalne skupiska diaspory arabskiej. Respondenci z diaspory arabskiej byli rekrutowani z zachowaniem podziału według daty przyjazdu do Polski - tych, którzy przyjechali do Polski w ostatnich latach, uznać można za „nową” diasporę (50 respondentów - w tekście oznaczeni skrótem ND), natomiast ci, którzy przyjechali do Polski przed 1989 r. i tu pozostali, tworzą „starą” diasporę arabską w Polsce (50 respondentów - w tekście oznaczeni skrótem SD).

Do badania m.in. starej diaspory została zastosowana technika indywidualnych wywiadów pogłębionych, do badania nowej diaspory i Polaków - kwestionariusz ankiety z pytaniami zamkniętymi. Wśród badanych Polaków wyodrębniły się trzy grupy: Polacy przychylni (w tekście oznaczeni skrótem PP), nieprzychylni (oznaczeni skrótem PN) oraz „niezdecydowani” (oznaczeni skrótem TP), czyli tacy, którzy

\footnotetext{
10 Jeden z przedstawicieli diaspory przyjechał do Polski w 1969 r.

11 Projekt został sfinansowany ze środków Narodowego Centrum Nauki przyznanych na podstawie decyzji numer DEC-2011/03/N/HS6/04744.

12 Metoda kuli śnieżnej polega na tworzeniu małej próby ze znanych elementów, próba ta następnie powiększa się o nowych członków, wskazywanych (polecanych) przez osoby już zbadane - stąd nazwa doboru próby odwołująca się do analogii z powiększająca się w trakcie toczenia kulą śnieżną; za: Słownik socjologii i nauk społecznych, red. G. Marshall, PWN, Warszawa 2006, s. 383.
} 
na pytanie: czy jesteś przychylny arabskiej społeczności w Polsce? wybrali odpowiedź: „trudno powiedzieć". Najwięcej osób - około 2/3 badanych Polaków określiło siebie jako przychylnych, najmniej jako nieprzychylnych badanej społeczności. Osoby niezdecydowane podawały jako wyjaśnienie tego wyboru najczęściej fakt, że nie mają nic przeciwko pojedynczym osobom pochodzenia arabskiego, są jednak przeciwne masowej imigracji z krajów arabskich ${ }^{13}$.

Obydwie grupy badanych (polscy i arabscy respondenci) wypowiedzieli się o polityce migracyjnej Polski. Większość badanych nieprzychylnych i niezdecydowanych Polaków nie potrafi ocenić, czy w Polsce jest praktycznie określona polityka migracyjna, podobnie uważa około 2/3 Polaków przychylnych, argumentując zwykle: „nie znam polityki migracyjnej. Nigdy mnie to nie dotyczyło, więc się nie interesowałam" (PP54). Również około 1/3 badanych polskich respondentów nie potrafi ocenić, czy Polsce jest potrzebne określenie dokładnych reguł polityki migracyjnej (bo $\mathrm{w}$ większości nie mają wiedzy na ten temat), natomiast około połowa uważa, iż jest to niezbędne, ponieważ m.in. służy to poprawie funkcjonowania państwa i imigrantów w Polsce oraz regulacji przyjazdów imigrantów. Tylko kilka osób stwierdziło, że Polska nie potrzebuje dokładnie regulować polityki migracyjnej, ponieważ m.in. „obecne reguły są wystarczające” (PP55), „mało reguł istotniejszych jest w Polsce określonych" (TP15).

Większość badanych przedstawicieli arabskiej diaspory (w tym około połowa przedstawicieli starej diaspory) uważa, że w Polsce jest praktycznie określona polityka migracyjna, co potwierdzają przykładowe komentarze: „tak, nie było, teraz jest dyscyplina, jest wizja polityczna, ale jeszcze nie weszli w praktykę" (ND46), ,jest, ale jest otwarta i niekompletna, nie jest wyraźnie określone, czego oni chcą od imigrantów, luźna jest ta polityka" (SD10); około jedna trzecia badanych jest przeciwnego zdania, bo uważają m.in., że jest prawo unijne; a kilkanaście osób nie ma sprecyzowanego zdania na ten temat.

Również zdecydowana większość przedstawicieli arabskiej diaspory uważa, że Polsce jest potrzebne określenie dokładnych reguł polityki migracyjnej, żeby m.in. imigranci wiedzieli, czego się od nich oczekuje jeszcze przed przyjazdem do Polski, ponadto zależy im na kontroli legalności i bezpieczeństwa pobytu, tylko kilkanaście osób jest przeciwnego zdania, bo twierdzą (jak badani Polacy), że istniejące przepisy są wystarczające lub nie mają opinii na ten temat.

${ }^{13}$ Szczegółowa metodologia (triangulacja) i analiza badań znajduje się w przygotowanej rozprawie doktorskiej. 


\section{Historia polityki migracyjnej w Polsce}

W rzeczywistości polityka migracyjna w Polsce to stosunkowo nowy przedmiot badań i szczegółowych uregulowań prawnych. Jest to polityka w fazie ustaleń - ewoluująca od 1926 r., kiedy to ogłoszono rozporządzenie Prezydenta Rzeczypospolitej o cudzoziemcach (ówczesna definicja cudzoziemca, że jest nim każdy, kto nie posiada obywatelstwa polskiego, obowiązuje do dziś). Kolejnym wydarzeniem była ustawa o obywatelstwie polskim (1962 r.) i ustawa o cudzoziemcach (1963 r.).

Dopiero po zmianie systemu politycznego kwestie migracji stały się przedmiotem kolejnych regulacji. W latach transformacji (1989-2001) ustawodawstwo dotyczące migracji przeszło fazę instytucjonalizacji, ogłoszono wówczas m.in. ustawę o zatrudnieniu wprowadzającą system zezwoleń na pracę cudzoziemców (1989r.), podpisano Konwencję genewską w sprawie statusu uchodźców z 1951 r. i Protokół nowojorski z 1967 r. (1991 r.) oraz nową ustawę o cudzoziemcach (1997 r.).

W latach 2001-2004, przed akcesją do Unii Europejskiej, nastąpiła europeizacja polskiego prawa migracyjnego, w tym m.in. w 2001 r. ustanowiono Urząd ds. Repatriacji i Cudzoziemców (w 2007 r. przekształcony w Urząd ds. Cudzoziemców), w 2003 r. wprowadzono nową ustawę o cudzoziemcach, w tym samym roku przeprowadzono też pierwszą tzw. małą abolicję dla cudzoziemców nielegalnie przebywających w Polsce, a w 2004 r. wprowadzono ustawę o promocji zatrudnienia i instytucjach rynku pracy oraz ustawę o pomocy społecznej, wprowadzającą uregulowania o programach integracyjnych dla uchodźców.

Od 2004 r. trwa faza stabilizacji prawnych migracji, m.in. utworzono Departament Polityki Migracyjnej w Ministerstwie Spraw Wewnętrznych i Administracji (2006 r.) i Międzyresortowy Zespół ds. Migracji (2007 r.), ustanowiono Kartę Polaka i przeprowadzono drugą abolicję (2007 r.), w tymże roku także Polska dołączyła do obszaru Schengen - tym samym zniesiono kontrole na wewnętrznych granicach lądowych i morskich, a w 2008 r. także w ruchu powietrznym, natomiast w 2009 r. uchwalono nową ustawę o obywatelstwie polskim ${ }^{14}$. W 2012 r. przeprowadzono trzecią abolicję oraz przyjęto przez Radę Ministrów najważniejszy co do unormowania migracji w Polsce akt, uwzględniający dotychczasowy stan prawny, czyli dokument zawierający założenia polskiej polityki migracyjnej pt. „Polityka migracyjna Polski - stan obecny i postulowane działania" nazywany strategią migracyjną. Jest to dokument

${ }_{14}$ M. Lesińska, R. Stefańska, M. Szulecka, Rozwój polityki migracyjnej Polski, w: Transformacja nieoczywista. Polska jako kraj imigracji, red. A. Górny, I. Grabowska-Lusińska, M. Lesińska, M. Okólski, Wydawnictwa UW, Warszawa 2010, s. 262-264. 
programowy przygotowany przez grupę roboczą ds. przygotowania strategii migracyjnej Polski, powołaną w ramach Zespołu ds. Migracji, po konsultacjach z organizacjami pozarządowymi i przedstawicielami środowisk naukowych. Dokument ten w dużej mierze pokrywa się z rekomendacjami przedstawionymi we wnioskach ogólnych publikacji „Transformacja nieoczywista. Polska jako kraj imigracji”"

Dokument ten zawiera przegląd i ocenę aktualnej sytuacji migracyjnej Polski $\mathrm{w}$ aspekcie międzynarodowych uwarunkowań polityki migracyjnej Polski oraz jej związku z innymi rodzajami polityki w Polsce wraz z wnioskami i rekomendacjami co do kolejnych działań w tym zakresie przez odpowiednie instytucje. Już w oparciu o ten dokument wprowadzono nowe rozwiązania prawne i instytucjonalne w nowej ustawie o cudzoziemcach z 2013 r. Akt ten zawiera rozwiązania ułatwiające wszystkim cudzoziemcom przebywającym w Polsce legalizację, zapobiegając również delegalizacji ich pobytu na terytorium Polski. Zamierzeniem ustawodawcy było uporządkowanie w nim problematyki pobytu cudzoziemców, nadanie przepisom większej przejrzystości i wprowadzenie przyspieszenia oraz uproszczenia procedur udzielania wszystkich zezwoleń pobytowych ${ }^{16}$. Zaobserwowali to przedstawiciele arabskiej diaspory, co skomentował jeden z respondentów: „próbują zintegrować imigrantów ze społeczeństwem, w wielu przypadkach ułatwiają kwestie pobytu i pracy i moim zdaniem podchodzą prawnie na zasadzie równouprawnienia, bez odróżniania czy Polak, czy imigrant" (ND39).

\section{Kategoryzacja imigrantów a arabska diaspora}

Jednym z priorytetowych postulatów ww. dokumentu jest dostosowanie polityki migracyjnej do priorytetów rynku pracy (przy utrzymaniu uzupełniającego charakteru zatrudniania imigrantów zarobkowych względem pracowników lokalnych) oraz zapewnienie konkurencyjności polskiej gospodarki ${ }^{17}$. W tym aspekcie za najważniejsze dla Polski uznano przyjmowanie (wśród innych uprzywilejowanych grup) zwłaszcza imigrantów o stosunkowo wysokim potencjale aktywności zawodowej, przy równoczesnym dużym zainteresowaniu osiedleniem się i procesem integracji,

\footnotetext{
15 M. Lesińska, R. Stefańska, M. Szulecka, Podsumowanie z perspektywy polityki migracyjnej, w: Transformacja nieoczywista. Polska jako kraj imigracji, red. A. Górny, I. Grabowska-Lusińska, M. Lesińska, M. Okólski, Wydawnictwa UW, Warszawa 2010, s. 237-249.

16 Ustawa z dnia 12 grudnia 2013 r. o cudzoziemcach, DzU 2013, poz. 1650.

17 Polityka migracyjna Polski - stan obecny i postulowane działania, Zespół ds. Migracji MSW, Warszawa 2012, s. 14.
} 
inwestorów i podmioty gospodarcze zainteresowane prowadzeniem działalności gospodarczej w Polsce oraz wykwalifikowanych absolwentów polskich uczelni i wysoko kwalifikowanych pracowników ${ }^{18}$. Jest to założenie zgodne z opinią Paula Scheffera, który twierdzi, że z nisko kwalifikowanych imigrantów nie ma korzyści ${ }^{19}$ i że imigranci powinni być dobrze wykształceni ${ }^{20}$.

Biorąc pod uwagę, że imigracja to napływ ludności obcej do jakiegoś kraju w celu osiedlenia się czasowo lub na stałe oraz ludność cudzoziemska osiadła czasowo bądź na stałe w jakimś kraju ${ }^{21}$, w świetle powyższej definicji przedstawiciele arabskiej diaspory nie są klasycznymi imigrantami, którzy przyjechali do Polski z zamiarem osiedlenia się - większość stanowią osoby, które przyjechały na studia (w tym prawie wszyscy respondenci ze starej diaspory), z powodu małżeństwa z obywatelką Polski i kilka osób z powodu pracy (tylko przedstawiciele nowej diaspory), nieliczne osoby z nowej diaspory stwierdziły, że przyjechały do Polski na emigrację, czyli w celu polepszenia swojej sytuacji życiowej. Jednakowo dla przedstawicieli starej i nowej diaspory najważniejszym motywem pozostania w Polsce jest egzogamiczne małżeństwo, na drugim miejscu jest praca, na trzecim miejscu dla starej diaspory jest brak możliwości powrotu, dla nowej z kolei studia.

Oznacza to, że członkowie diaspory arabskiej w Polsce należą do ww. uprzywilejowanych grup cudzoziemców ${ }^{22}$, ponieważ są wśród nich:

a) Studenci, naukowcy i absolwenci polskich uczelni oraz imigranci zarobkowi o potrzebnych kwalifikacjach - zdecydowana większość badanych przedstawicieli diaspory arabskiej w Polsce to ludzie z minimum wyższym wykształceniem, żaden $\mathrm{z}$ respondentów nie miał wykształcenia niższego niż średnie. Poza tym część przedstawicieli społeczności arabskiej w Polsce pracuje w wysoko kwalifikowanych zawodach, m.in. jako nauczyciele, wykładowcy, naukowcy, lekarze, inżynierzy. Ponadto badani przedstawiciele diaspory arabskiej w Polsce oprócz języka arabskiego i polskiego zgłaszali jeszcze znajomość minimum jednego z kilkunastu innych języków.

b) Cudzoziemcy prowadzący działalność gospodarczą i kreujący nowe miejsca pracy - najliczniejsza grupa arabskich respondentów - około połowa prowadzi własne firmy (m.in. handlowe, budowlane, szkoleniowe, gastronomiczne), w których zatrudniają Polaków, tworząc miejsca pracy.

\footnotetext{
18 Ibidem, s. 34.

19 P. Scheffer, Druga ojczyzna. Imigranci w społeczeństwie otwartym, Wydawnictwo Czarne, Wołowiec 2010 , s. $137-141$.

20 Ibidem, s. 156.

${ }^{21}$ Socjologia. Przewodnik encyklopedyczny, Wydawnictwo Naukowe PWN, Warszawa 2008, s. 118.

22 Polityka migracyjna Polski..., op.cit., s. 14.
} 
c) Członkowie rodzin obywateli polskich (kilkunastu badanych respondentów z nowej diaspory przyjechało do Polski z powodu małżeństwa - są to tzw. migracje $\mathrm{z}$ miłości (love migrants), czyli migracje związane z utworzeniem sformalizowanego bądź wolnego związku²3.

d) Osoby objęte ochroną na terytorium RP (dwie osoby miały w chwili badania status uchodźcy).

Sami przedstawiciele arabskiej społeczności w Polsce nie uważają się za imigrantów, szczególnie ci ze starej diaspory - zdecydowana większość ma polskie obywatelstwo (z czego prawie połowa twierdzi, że czuje się Polakami), pozostali - kartę stałego pobytu. Część z nich generalizowała, że w Polsce nie ma klasycznych imigrantów, jak w przypadku krajów zachodnich, co potwierdza wypowiedź jednego z respondentów: „generalnie rzecz biorąc, nie ma imigrantów w Polsce, mieszkają tu tylko ci, którzy wcześniej byli studentami” (SD19).

Badani przedstawiciele diaspory przebywają w Polsce z powodu studiów, małżeństwa, biznesu lub sytuacji w swoim kraju, do Polski przywiódł ich zatem bardziej los i przypadek niż celowy wybór. Z racji braku imigrantów w Polsce (bądź ich marginalnej liczebności) tematykę polityki migracyjnej część arabskich respondentów uważa za kwestię ewentualnej przyszłości, nie widząc potrzeby unormowania jej w najbliższym czasie.

\section{Skala imigracji a polityka migracyjna Polski}

Biorąc pod uwagę, że Polska należy do państw unijnych, które stają się dopiero krajami docelowymi dla imigrantów i skala migracji do Polski jest raczej marginalna (zwiększone zainteresowanie pobytem w Polsce cudzoziemców jest zauważalne dopiero od $2008 \mathrm{r}^{24}$ ), a liczebność cudzoziemców jest niewielka, wręcz incydentalna w stosunku do całej populacji, oscylując w granicy $0,5 \%{ }^{25}$, może nie dziwić fakt, że polityka migracyjna nie jest jeszcze ustalona i jej określenie nie jest priorytetem. $\mathrm{Na}$ uznanie zasługuje fakt, że przy tak niskim poziomie liczby imigrantów polskie władze stopniowo podejmują działania zmierzające do poprawy sytuacji cudzoziemców przebywających w Polsce i ich integracji z polskim społeczeństwem. Świadczy to o wzroście znaczenia tej problematyki dla przyszłości Polski, choć wydawałoby

\footnotetext{
23 J. Kubitsky, Psychologia migracji, Difin, Warszawa 2012, s. 9-11.

${ }^{24}$ Polityka migracyjna Polski..., op.cit., s. 9.

25 Ibidem, s. 118.
} 
się, że na poruszanie jej jest zbyt wcześnie. Jedna z ekspertek ds. migracji, Patrycja Matusz-Protasiewicz stwierdziła jednak: „Analizując doświadczenia innych krajów europejskich, możemy zauważyć, że niektóre państwa, jak na przykład Finlandia (miasto Helsinki), wprowadzały programy stymulujące przedsiębiorczość imigrantów i przeciwdziałające ich wykluczeniu na rynku pracy, kiedy liczba imigrantów była na poziomie $1 \%$ ogółu populacji”26.

\section{Monitoring procesów migracyjnych}

Wracając do definicji polityki migracyjnej, w zakresie kontroli wjazdu (i wyjazdu) cudzoziemców do Polski słuszny jest postulat monitoringu procesów migracyjnych ${ }^{27}$, ponieważ w trakcie badań terenowych okazało się, że w urzędowych statystykach dotyczących liczby cudzoziemców w Polsce brakuje dokładnych informacji o osobach narodowości arabskiej (dane ze zbiorów meldunkowych nie są adekwatne do danych Urzędu ds. Cudzoziemców odnośnie do liczby ważnych kart pobytu ${ }^{28}$. Poza tym dla zarządzania procesami migracji i monitorowania tego zjawiska ważne jest poznanie przyczyn migracji oraz sytuacji w kraju imigranta ${ }^{29}$.

\section{Dostęp imigrantów do rynku pracy}

Drugim elementem przyjętej we wstępie definicji polityki migracyjnej jest dostęp cudzoziemców do rynku pracy. W rozpatrywanym dokumencie strategicznym są w tym zakresie pewne sprzeczności - z jednej strony optowano za stanowiskiem, że „zatrudnianie cudzoziemców powinno mieć charakter komplementarny w stosunku do zasobów siły roboczej” ${ }^{30}$, z drugiej strony tworzone warunki na rynku pracy

26 P. Matusz-Protasiewicz, Strategia migracyjna Polski - co z integracja?, http://biuletynmigracyjny.uw.edu. pl/29-maj-2011/strategia-migracyjna-polski-co-z-integracja

27 Polityka migracyjna Polski..., op.cit., s. 133-140.

${ }^{28}$ Wiele innych źródeł wskazuje brak rzetelnych danych statystycznych dotyczących zjawiska migracji w Polsce, m.in. Mobilność i migracje $w$ dobie transformacji. Wyzwania metodologiczne, red. P. Kaczmarczyk, Wydawnictwo Naukowe Scholar, Warszawa 2011, s. 14-18.

29 A. Gadowska, A. Spyra, Sz. Strzelichowski, K. Trzaska, A. Urban-Toczek, T. Witkowski, A. Ziębacz, Cudzoziemcy w województwie małopolskim - wybrane statystyki. Prawo migracyjne. Polityka migracyjna Polski, w: Imigranci $w$ Małopolsce. Między integracja, asymilacją, separacją, marginalizacją, red. E. Pindel, Akademia Ignatianum, Kraków 2014, s. 12.

30 Polityka migracyjna Polski..., op.cit., s. 33. 
powinny zachęcać studentów zagranicznych oraz absolwentów polskich uczelni do osiedlania się i zasilania swoimi kwalifikacjami rynku pracy ${ }^{31}$, ponieważ „zagraniczni studenci stanowią dla Polski niezwykle ważną grupę imigrantów, która w naturalny sposób, dzięki nauce na polskich uczelniach, zyskuje zasadniczy kapitał wiedzy i potencjał integracyjny, który może zostać wykorzystany w wypadku ich dalszego pobytu w Polsce po zakończeniu edukacji”"32.

Są to okoliczności wzajemnie się wykluczające - mając do wyboru Polaka lub cudzoziemca $z$ podobnym wykształceniem i umiejętnościami, pracodawca, korzystając z zasady komplementarności, może dać pierwszeństwo zatrudnienia Polakowi. Tę możliwość potwierdzają m.in. badania Instytutu Spraw Publicznych w ramach programu „Różni, ale równi - badania nad równym traktowaniem cudzoziemców w Polsce", które polegały m.in. na przeprowadzeniu tzw. testów dyskryminacyjnych na polskim rynku pracy wśród polskich pracodawców. Badani pracodawcy byli bardziej skłonni zatrudnić Polaka niż cudzoziemca o tych samych kwalifikacjach ${ }^{33}$.

Państwo powinno przeciwdziałać dyskryminacji na rynku pracy (poprzez działania antydyskryminacyjne - zdefiniowanie dyskryminacji, możliwości zgłaszania, określenie metod reakcji państwa, ewentualne sankcje lub kary, wsparcie dla poszkodowanych) ${ }^{34}$. W przypadku działań na rzecz ograniczania dyskryminacji na rynku pracy można wykorzystać badania kanadyjskiego profesora, Jeffa Pfeifera, wykorzystane do opracowania szeregu programów warsztatów antydyskryminacyjnych, w których efekcie z powodzeniem zredukowano przejawy dyskryminacji na rynku pracy i w systemie sprawiedliwości w Kanadzie, w działalności policji w Kanadzie i Australii oraz w australijskich systemach penitencjarnych. Za podstawę rasizmu uznał on brak doświadczenia i osobistej wiedzy ${ }^{35}$.

$\mathrm{Na}$ marginesie warto zwrócić uwagę, że regulacje dostępu cudzoziemców do rynku pracy nie były poprzedzone badaniami popytu na pracę cudzoziemców przez pracodawców na polskim rynku pracy. Ostatnie takie badania były przeprowadzone w 2007 r., wówczas zdecydowana większość firm nie planowała zatrudnienia

31 Ibidem, s. 34.

32 Ibidem, s. 39.

33 Por. K. Wysieńska, Nguyen, Serhij, czy Piotr? Pilotażowe badanie audytowe dyskryminacji cudzoziemców w rekrutacji, Fundacja Instytut Spraw Publicznych, Warszawa 2010; http://www.isp.org.pl/projekty,rozni, - ale-rowni-badania-nad-rownym-traktowaniem-cudzoziemcow-w-polsce,664.html [dostęp 16.08.2014]; K. Wysieńska, Testy dyskryminacyjne - metoda i zastosowania, w: W poszukiwaniu nowych wzorów integracji cudzoziemców. Wybór tekstów polskiego forum integracyjnego, red. J. Segeš-Frelak, K. Grot, Fundacja Instytut Spraw Publicznych, Warszawa 2013, s. 210-213.

34 M. Lesińska, R. Stefańska, M. Szulecka, Podsumowanie z perspektywy..., op.cit., s. 245.

35 C.A. Meissner, J.C. Brigham, J.E. Pfeifer, Jury nullification: The influence of judicial instruction on the relationship between attitudes and juridic decision-making, „Basic \& Applied Social Psychology” 2003, Nr 25, s. 243-254. 
cudzoziemca ${ }^{36}$. Według danych Ministra Pracy i Polityki Socjalnej w 2007 r. chęć zatrudnienia cudzoziemca zadeklarowało 21797 firm, a w 2011 r. już 259777 firm ${ }^{37}$, jednak te dane zostały opublikowane dopiero w maju 2014 r., zatem już po przyjęciu dokumentu o polityce migracyjnej.

Jak twierdzi Michał Polakowski, w przypadku integracji cudzoziemców widać całkowitą bierność pracodawców ${ }^{38}$, pracodawcy wydają się nie być zainteresowani tematem zatrudnienia cudzoziemców, nie są także prowadzone badania pod tym kątem. Jedno z niewielu badań pracodawców - badanie sondażowe MLPM (Migration Policy and Labour Market Change) z 2007 r. dowiodło, że rola pracowników cudzoziemskich na polskim rynku pracy była zdecydowanie komplementarna. Jak dotąd nie widać wpływu pracowników cudzoziemskich na polską gospodarkę z uwagi na ich niewielką rolę odgrywaną na rynku pracy (mała skala rejestrowanego napływu cudzoziemców do Polski) ${ }^{39}$.

Dodatkowo w 2007 r. zbadano stosunek Polaków do cudzoziemców na rynku pracy - $28 \%$ badanych Polaków uważało wówczas, że cudzoziemcy odbierają pracę osobom urodzonym w Polsce, a $48 \%$ - że przybysze z innych krajów przyczyniają się do rozwoju polskiej gospodarki ${ }^{40}$. Obydwie opinie znalazły się wśród wypowiedzi respondentów moich badań: „[Arabowie - przyp. M.S.] zabierają pracę Polakom” (PN8), „każdy rozwinięty kraj korzysta na obecności imigrantów kulturowo i ekonomicznie" (PP24).

Przedstawiciele diaspory arabskiej wśród problemów dnia codziennego wymienili m.in. kłopoty z pracą (brak pracy lub problemy z nią związane), przy czym tylko kilka osób określiło swój status jako bezrobotny (z czego tylko jedna ze starej diaspory). Fakt, że mniej problemów ze znalezieniem pracy mają reprezentanci starej diaspory, może być wynikiem m.in. dobrej znajomości języka polskiego i wysokiego stopnia integracji (studia w języku polskim) oraz dłuższego pobytu w Polsce (członkowie starej diaspory mieszkają w Polsce 25-45 lat).

${ }^{36}$ I. Grabowska-Lusińska, Skala i struktura popytu na prace cudzoziemców w Polsce w świetle przeprowadzonych badań, w: Czy Polska gospodarka potrzebuje cudzoziemców?, red. I. Grabowska-Lusińska, A. Żylicz, Ośrodek Badań nad Migracjami WNE UW, Warszawa 2008, s. 60.

37 P. Kaczmarczyk, Recent Trends in International Migration in Poland The 2012 SOPEMI Report, „CMR Working Paper" 2014, Nr 71/129, s. 36.

${ }_{38}$ M. Polakowski, Projekty integrujące imigrantów w dziedzinie polityki społecznej i rynku pracy, w: Polityka (dez)integracji. Zarzadzanie integracją obywateli państw trzecich $w$ Polsce, red. P. Pawlak, D. Szelewa, M. Polakowski, M. Fijałkowska, I. Bąbiak, Wydawnictwo Naukowe Scholar, Warszawa 2010, s. 52.

39 A. Janicka-Żylicz, P. Kaczmarczyk, Ekonomiczne skutki napływu cudzoziemców i perspektywy na przyszłość, w: Transformacja nieoczywista. Polska jako kraj imigracji, red. A. Górny, I. Grabowska-Lusińska, M. Lesińska, M. Okólski, Wydawnictwa UW, Warszawa 2010, s. 181-184.

40 E. Jaźwińska, Stosunek Polaków do cudzoziemców na polskim rynku pracy, w: Czy Polska gospodarka potrzebuje cudzoziemców?, red. I. Grabowska-Lusińska, A. Żylicz, Ośrodek Badań nad Migracjami WNE UW, Warszawa 2008, s. 55-56. 
Przy kwestii pracy warto też zwrócić uwagę, że Arabowie w Polsce kojarzą się głównie z lokalami gastronomicznymi potocznie zwanymi kebabami; na pytanie gdzie spotykasz osoby arabskiego pochodzenia, jeden z Polaków odpowiedział: „nie spotykam, tylko widuję, bo nie korzystam” („kupując kebaba, osiedlasz Araba”) (PN3), choć lokale te są prowadzone także przez Polaków czy przedstawicieli innych narodowości, a Arabowie nie pracują tylko w takich miejscach - wśród stu respondentów arabskiej diaspory tylko kilku pracuje lub jest właścicielem lokalu gastronomicznego.

Badani reprezentanci arabskiej diaspory to niewykorzystywany w pełni potencjał. Jak już wspomniano, członkowie arabskiej społeczności ukończyli studia. Jeśli nawet Arab pracuje w lokalu gastronomicznym, to jest osobą wykształconą, a pracuje $\mathrm{w}$ nim prawdopodobnie $\mathrm{z}$ konieczności, a nie $\mathrm{z}$ wyboru. Ten rodzaj pracy jest traktowany przez nich jako praca przejściowa, tymczasowa. Praca w gastronomii jest czasami jedyną możliwością zarobku, kiedy nie można znaleźć innej pracy. Jest to problem zwłaszcza osób z nowej diaspory arabskiej, kiedy brak dobrej znajomości języka polskiego utrudnia znalezienie pracy zgodnej z kwalifikacjami i wykształceniem (kilka osób z nowej diaspory przyznało, że zna język polski słabo). Dla wielu osób z nowej diaspory ta praca w gastronomii stanowi rodzaj piętna i „błędne koło”, z którego ciężko się wydostać - trafiają do pracy w gastronomii, bo nie znają dobrze polskiego języka, jednak w tej pracy nie ma możliwości i czasu na naukę języka czy integrację, więc są skazani na tego typu pracę na dalsze lata pobytu w Polsce, tym bardziej że gdy poszukują pracy zgodnej z wykształceniem, doświadczenie w lokalu gastronomicznym nie jest mile widziane przez pracodawców, z drugiej strony wypracowane kontakty umożliwiają im pozostanie w branży.

Zdaniem większości respondentów (i polskich, i arabskich) najkorzystniejszym wyjściem z sytuacji byłyby programy integracyjne z bezpłatną nauką języka polskiego, pozwalające nowo przybyłym imigrantom na stosunkowo szybkie wejście na polski rynek pracy, aby mogli w pełni wykorzystywać posiadaną wiedzę i zdobyte umiejętności - także na rzecz polskiego społeczeństwa i gospodarki.

Sami polscy Arabowie dostrzegają zależność pomiędzy pracą a integracją: „[integracja - przyp. M.S.] tych nowo przybyłych jest słaba, bo oni nie pracują bezpośrednio z Polakami jak ja, pracuję z nimi osiem godzin, czyli jestem obecny wśród Polaków dłużej niż z moimi dziećmi, teraz przyjeżdżający Egipcjanin, nawet żonaty z Polką nie integruje się z Polakami w jego restauracji, jedyny kontakt to z klientem, który kupuje od niego jedzenie albo kanapkę” (SD41); „[... ] we Francji, Niemczech, Anglii są programy dla imigrantów, od razu po przyjeździe imigranta organizują mu kurs językowy, uczą zawodu i wtedy zaczyna się integracja ze społeczeństwem, przez pracę, ale w Polsce nie ma takich programów, nie tylko dla Arabów, nie ma programów integracyjnych [...], jeśli ja zrobię tu kurs mechanika, po jego skończeniu zaczyna 
się praca i wtedy zaczyna się integracja, a jeśli tu w Polsce nic nie ma, tylko kebaby i tam wszyscy Arabowie albo muzułmanie pracują, więc jak ma nastąpić integracja?” (ND48), tym samym powyższa wypowiedź potwierdza opinię twórców dokumentu o polityce migracyjnej, według których podstawą funkcjonowania imigranta w społeczeństwie jest dostęp do rynku pracy i znajomość języka polskiego oraz znajomość i stosowanie kulturowych reguł postępowania ${ }^{41}$. Potwierdza to też opinia Hana Entzingera i Renske Biezevelda, że pierwszy symptom sukcesu integracji jest powiązany z uczestnictwem imigrantów w rynku pracy (ewentualnie samozatrudnienie) oraz z czynnikami mającymi na to wpływ, jak edukacja czy znajomość języka ${ }^{42}$.

\section{Społeczna akceptacja imigrantów}

Co do akceptacji społecznej imigrantów, większość badanych Polaków przychylnych arabskiej diasporze ma otwarte podejście do społeczności arabskiej i innych imigrantów, jednak większość akceptuje ich pod warunkiem poszanowania prawa. Podobnie uważa większość arabskich respondentów. Wydawałoby się, że Polacy i Arabowie (uznawani w moich badaniach przez większość Polaków za bardzo od siebie odległych kulturowo) bardzo się między sobą różnią, jednak w przeprowadzonym badaniu wiele opinii obydwu badanych grup było zbieżnych. Także problem imigracji i kwestie jej pokrewne Polacy i Arabowie postrzegają podobnie - są przeciwni dużej liczbie imigrantów w Polsce: „nadmierna migracja jest niekorzystna” (PN1); „ja jestem przeciwko imigracji zarobkowej, ja wolę mieszkać w Polsce niż np. w Niemczech, bo w Niemczech jest za dużo obcokrajowców, a to męczy człowieka, bo powoduje, że są pewne zmiany i te zmiany czasami nie są najlepsze" (SD20), uważają, że imigracja powinna nadal mieć selektywny, ograniczający charakter: „jeśli Polska potrzebuje lekarzy, to ściąga lekarzy, albo innych profesjonalistów, a nie każdego brać z ulicy, bo wtedy zaczynają się problemy” (SD30); „jeśli mówimy o Arabie, który tu pracuje, płaci podatki i jest dobrym obywatelem? Jasne, ale jeśli to radykał i oszołom, jakich pełno w Wielkiej Brytanii, to stanowczo nie - wydalić, i to w trybie pilnym" (PP17).

Arabowie są krytyczni wobec siebie i innych Arabów, zwłaszcza w stosunku do najnowszej fali nowej diaspory, uważają, że w Polsce powinny mieć prawo pobytu tylko osoby respektujące prawo. „Polscy Arabowie” opinię co do polityki migracyjnej

${ }^{41}$ Polityka migracyjna Polski..., op.cit., s. 72.

${ }^{42} \mathrm{H}$. Entzinger, R. Biezeveld, Zasady integracji imigrantów, w: Integracja kulturowa imigrantów. Wyzwania i dylematy, red. J. Balicki, Instytut Politologii UKSW, Fundacja Konrada Adenauera, Warszawa 2007, s. 43. 
Polski mają podobną do polskich władz i polskiego społeczeństwa, twierdząc ponadto, że wielokulturowość może być kłopotliwa: „imigracja już stała się problemem, przez który cierpią nawet kraje rozwinięte. Imigracja ekonomiczna w celu szukania środków do życia jest to duży problem" (SD50); [...] gdzie jest wielokulturowość, są problemy” (SD31); „Związać politykę migracyjną z określonymi dokładnymi regułami zgodnie z potrzebami społecznymi, druga rzecz - ograniczać aspekt liczbowy, nie można otworzyć drzwi na oścież [...], co za dużo to niezdrowo" (SD42).

Arabscy respondenci nie chcą tu podobnych kłopotów z imigrantami, co w zachodnich krajach masowej imigracji typu Niemcy, Wielka Brytania czy Francja. Imigracje do Polski, według nich, powinny pozostać na teraźniejszym poziomie, pod kontrolą. Są ponadto za przyjmowaniem tylko „dobrych” i przydatnych imigrantów, którzy będą Polsce przynosić korzyści, a nie straty i problemy: „przede wszystkim to człowiek normalny, kulturalny ma cechy pozytywne, może przynieść korzyści Polsce, nie tylko być obciążeniem dla Polaków” (SD1); „akceptuję tych, którzy włączyli się swoją pracą $\mathrm{w}$ funkcjonowanie społeczeństwa i państwa. Z konieczności akceptuję przybyszów, którzy opuścili swój kraj z powodu konfliktów” (PP6); „odsiewanie tych, co są za dużym zagrożeniem, bądź nie chcą się zasymilować” (PP17).

Zatem ustalenie polityki migracyjnej dla Polski (selektywnej) jest kwestią niewątpliwie wskazaną, pomimo niewielkiej obecnie liczby imigrantów - dla wykorzystania w pełni potencjału społeczno-gospodarczego także tej grupy społeczeństwa. A gdyby jednak w dalszej perspektywie nastąpił znaczący wzrost imigracji, to Polska, mając ustaloną politykę migracyjną, ma szansę nie powtórzyć błędów innych krajów wielokulturowych. Dobrym wstępem do jej utworzenia jest omawiany dokument o polityce migracyjnej, który powoli z teorii zmieniany jest w praktykę. Wysiłki państwa zauważyli też badani respondenci arabscy: „państwo próbuje przyrównać przebywających tu imigrantów do własnych obywateli, ale trafia na bariery" (ND29).

\section{Partycypacja imigrantów w tworzeniu prawa migracyjnego}

Oprócz uproszczenia procedur pobytowych i wzmocnienia struktur odpowiedzialnych za migracje, przebudowy systemu integracji i monitorowania cudzoziemców oraz zwiększenia roli organizacji pozarządowych i jednostek naukowo-badawczych zajmujących się szeroko rozumianą problematyką migracji zalecanych w omawianym dokumencie warto zastanowić się nad dodatkowym bezpośrednim i aktywnym włączeniem samych imigrantów w proces tworzenia praw i procedur, jakim podlegali bądź nadal podlegają (konsultacje z przedstawicielami imigrantów i zwiększenie 
zakresu współpracy ze środowiskami imigrantów jest zalecane w projekcie polityki integracyjnej ${ }^{43}$ ). Patrycja Matusz-Protasiewicz twierdzi, że jednym z największych błędów wielu krajów europejskich, w których imigranci byli przedmiotem polityki integracyjnej, było wykluczenie ich z jej aktywnego współtworzenia ${ }^{44}$.

Naturalne byłoby zatrudnianie znaturalizowanych imigrantów w instytucjach obsługujących cudzoziemców, konsultowanie z nimi inicjatyw podejmowanych na rzecz imigrantów, wykorzystywanie ich jako mentorów w rozwiązywaniu problemów danej społeczności i do oficjalnej pomocy nowym imigrantom. Przykładem tego typu inicjatywy jest powstanie Warszawskiego Centrum Wielokulturowego, konsultowanego m.in. ze społecznością palestyńską, czy pierwsze Forum Migracyjne zorganizowane w Warszawie we wrześniu 2014 r.

Ideałem byłoby stworzenie centrum informacyjnego dla imigrantów w każdym mieście wojewódzkim, w którym pracowaliby przedstawiciele największych społeczności imigranckich w Polsce. Takie centrum pełniłoby rolę pierwszego kontaktu z Polską dla danego cudzoziemca, gdzie otrzymałby kompleksową pomoc na temat legalizacji pobytu, możliwość pracy i zakwaterowania w swoim języku. Centrum informowałoby także o kursach języka polskiego, historii i kultury polskiej oraz programach integracyjnych i innych inicjatywach na rzecz imigrantów. Imigranci na miejscu mogliby skorzystać $\mathrm{z}$ komputerów $\mathrm{z}$ dostępem do internetu w celu przejrzenia baz danych (skonsolidowana baza ofert pracy i ofert wynajmu mieszkań dla cudzoziemców) i skorzystać z bezpłatnych porad. Takie centrum mogłyby być współfinansowane przykładowo przez ambasady krajów pochodzenia zatrudnionych $\mathrm{w}$ nich imigrantów bądź z programów unijnych. W dokumencie o polityce migracyjnej Polski również uznano, że w jednym miejscu powinny być zebrane wszelkie informacje dla cudzoziemców, m.in. z zakresu legalizacji pobytu, rynku pracy, edukacji czy integracji społecznej ${ }^{45}$.

Respondenci arabscy zwracali uwagę na kwestie braku obsługi przez imigrantów w urzędach wizowych. Pracujący tam Polacy ich zdaniem powinni być szkoleni, także w krajach, gdzie imigrantów jest dużo. Alternatywne jest zatrudnianie Polaków powracających z imigracji, takich, którzy rozumieją problemy i rozterki imigrantów - ludzi, którzy zostawili za sobą całe dotychczasowe życie - dom, rodzinę, wspomnienia, pracę. W kontaktach z imigrantami ważny jest aspekt ludzki, pierwiastek człowieczeństwa, bo przecież pod nazwą uchodźcy, imigranta, bezpaństwowca kryją się żywi ludzie. Migrant to tylko rola społeczna, należy więc zwrócić uwagę, że

${ }^{43}$ Projekt: Polska polityka..., op.cit., s. 19.

${ }^{44}$ P. Matusz Protasiewicz, op.cit.

45 Polityka migracyjna Polski..., op.cit., s. 132. 
imigracja to jednocześnie emigracja ze swojego kraju, co niesie także ze sobą wiele problemów. Migracja ma też ogromny wpływ na psychikę migranta, co się wiąże z kwestią zmiany tożsamości i systemu wartości oraz z szeregiem problemów psychicznych, uchodźcy np. często mają zespól stresu pourazowego ${ }^{46}$.

Warto byłoby zastanowić się także nad powołaniem krajowych bądź lokalnych reprezentantów wszystkich większych społeczności imigranckich w Polsce, korzystając na przykład ze struktury administracji publicznej lub w formie stowarzyszenia, którzy razem demokratycznie współtworzyliby politykę imigracyjną. Oznaczałoby to wykorzystanie w pełni możliwości demokratycznego państwa i społeczeństwa obywatelskiego. Niech to będą mężowie stanu, osoby cieszące się zaufaniem jednakowo swojej społeczności oraz społeczeństwa polskiego, pełniące prestiżową funkcję społeczną łącznika pomiędzy swoimi pobratymcami a Polakami, pracujący na rzecz wspólnego dobra Polski. W projekcie polityki integracyjnej określa się ich prawdopodobnie „ambasadorami społeczności migranckich”" ${ }^{\text {. }}$.

\section{Zakończenie}

Podsumowując, opinie badanych Polaków i członków arabskiej diaspory odnośnie do kwestii związanych z polską polityką migracyjną są zbliżone. Wypowiedzi respondentów posłużyły ponadto do opracowania konkretnych rozwiązań przydatnych do stworzenia właściwej polityki migracyjnej Polski oraz wykorzystania potencjału cudzoziemców przebywających w Polsce.

Na zakończenie warto podkreślić, że imigranci i społeczeństwo przyjmujące mają podobne problemy. Wyalienowanie i jego konsekwencje to największy problem imigrantów, przeżywają oni uczucie rozdzielenia i straty ${ }^{48}$. To poczucie straty przeżywa też społeczeństwo przyjmujące, mając odczucia zanikania znanych mu form współżycia ${ }^{49}$. Zatem społeczeństwo przyjmujące i imigrantów łączą uczucia straty i nostalgii, tęsknoty, choć przedmiotem tych uczuć są zupełnie inne kwestie. Jak zwrócił uwagę Paul Scheffer ${ }^{50}$, migrantów i społeczeństwa przyjmujące łączy także poczucie niepokoju o przyszłość. Z drugiej strony marzenie o znalezieniu oparcia w niespokojnym świecie oddala od siebie i starych, i nowych obywateli. Nawiązując do

\footnotetext{
46 Por. J. Kubitsky, op.cit.

47 Projekt: Polska polityka..., op.cit., s. 27.

48 P. Scheffer, op.cit., s. 16.

49 Ibidem, s. 19.

50 Ibidem, s. 21.
} 
baumanowskiej płynnej nowoczesności ${ }^{51}$, jako poczucia niepewności jednostki i braku pewności co do stabilnego jutra w dynamicznie zmieniających się globalnych warunkach, należałoby zwrócić baczniejszą uwagę na ten wspólny mianownik społeczności przyjmującej i imigrantów - wszak jutro każdy z nas może zostać imigrantem.

\section{Literatura}

Bauman Z., Płynna nowoczesność, Wydawnictwo Literackie, Kraków 2006.

Castles S., Miller M.J., The Age of Migration. International Population Movements in the Modern World, Guilford Press, New York 2003.

Chodubski A., Mniejszości narodowe w dziejach polskiej cywilizacji, w: A. Chodubski, Meandry cywilizacyjne, kwestie narodowościowe i polonijne, Wydawnictwo Adam Marszałek, Toruń 1996.

Chodubski A., Obraz imigracji w Polsce w latach dziewięćdziesiątych, w: Imigranci i społeczeństwa przyjmujące. Adaptacja? Integracja? Transformacja?, „Migracje i Społeczeństwo" 5, Wydawnictwo Neriton, Warszawa 2000.

Ekspertyza podsumowująca doświadczenia teoretyczne i empiryczne nad społecznym i ekonomicznym wymiarem integracji. Modut III. Integracja cudzoziemców w Polsce, Ośrodek Badań nad Migracjami WNE UW, Warszawa 2007.

Entzinger H., Biezeveld R., Zasady integracji imigrantów, w: Integracja kulturowa imigrantów. Wyzwania i dylematy, red. J. Balicki, Instytut Politologii UKSW, Fundacja Konrada Adenauera, Warszawa 2007.

Gadowska A., Spyra A., Strzelichowski Sz., Trzaska K., Urban-Toczek A., Witkowski T., Ziębacz T., Cudzoziemcy w województwie małopolskim - wybrane statystyki. Prawo migracyjne. Polityka migracyjna Polski, w: Imigranci w Małopolsce. Między integracja, asymilacją, separacją, marginalizacją, red. E. Pindel, Akademia Ignatianum, Kraków 2014.

Grabowska-Lusińska I., Skala i struktura popytu na pracę cudzoziemców w Polsce w świetle przeprowadzonych badań, w: Czy Polska gospodarka potrzebuje cudzoziemców?, red. I. Grabowska-Lusińska, A. Żylicz, Ośrodek Badań nad Migracjami WNE UW, Warszawa 2008.

Informacja o rozmiarach $i$ kierunkach emigracji $z$ Polski w latach 2004-2014, GUS, Warszawa 2015.

Janicka-Żylicz A., Kaczmarczyk P., Ekonomiczne skutki naptywu cudzoziemców i perspektywy na przyszłość, w: Transformacja nieoczywista. Polska jako kraj imigracji, red. A. Górny, I. Grabowska-Lusińska, M. Lesińska, M. Okólski, Wydawnictwa UW, Warszawa 2010.

${ }^{51}$ Por. Z. Bauman, Płynna nowoczesność, Wydawnictwo Literackie, Kraków 2006. 
Jaźwińska E., Stosunek Polaków do cudzoziemców na polskim rynku pracy, w: Czy Polska gospodarka potrzebuje cudzoziemców?, red. I. Grabowska-Lusińska, A. Żylicz, Ośrodek Badań nad Migracjami WNE UW, Warszawa 2008.

Kaczmarczyk P., Recent Trends in International Migration in Poland The 2012 SOPEMI Report, „CMR Working Paper” 2014, Nr 71/129.

Każmierkiewicz P., Segeš-Frelak J., Partycypacja publiczna i prawa polityczne obywateli państw trzecich na szczeblu krajowym i lokalnym, w: W poszukiwaniu nowych wzorów integracji cudzoziemców. Wybór tekstów polskiego forum integracyjnego, red. J. Segeš-Frelak, K. Grot, Fundacja Instytut Spraw Publicznych, Warszawa 2013.

Kubitsky J., Psychologia migracji, Difin, Warszawa 2012.

Lesińska M., Stefańska R., Szulecka M., Podsumowanie z perspektywy polityki migracyjnej, w: Transformacja nieoczywista. Polska jako kraj imigracji, red. A. Górny, I. Grabowska-Lusińska, M. Lesińska, M. Okólski, Wydawnictwa UW, Warszawa 2010.

Lesińska M., Stefańska R., Szulecka M., Rozwój polityki migracyjnej Polski, w: Transformacja nieoczywista. Polska jako kraj imigracji, red. A. Górny, I. Grabowska-Lusińska, M. Lesińska, M. Okólski, Wydawnictwa UW, Warszawa 2010.

Matusz-Protasiewicz P., Strategia migracyjna Polski - co z integracją?, http://biuletynmigracyjny.uw.edu.pl/29-maj-2011/strategia-migracyjna-polski-co-z-integracja

Meissner C.A., Brigham J.C., Pfeifer J.E., Jury nullification: The influence of judicial instruction on the relationship between attitudes and juridic decision-making, „Basic \& Applied Social Psychology" 2003, Nr 25.

Polakowski M., Projekty integrujące imigrantów w dziedzinie polityki społecznej i rynku pracy, w: Polityka (dez)integracji. Zarządzanie integracja obywateli państw trzecich $w$ Polsce, red. P. Pawlak, D. Szelewa, M. Polakowski, M. Fijałkowska, I. Bąbiak, Wydawnictwo Naukowe Scholar, Warszawa 2010.

Polityka migracyjna Polski - stan obecny i postulowane działania, Zespół ds. Migracji MSW, Warszawa 2012.

Scheffer P., Druga ojczyzna. Imigranci w społeczeństwie otwartym, Wydawnictwo Czarne, Wołowiec 2010.

Stownik socjologii i nauk społecznych, red. G. Marshall, PWN, Warszawa 2006.

Socjologia. Przewodnik encyklopedyczny, Wydawnictwo Naukowe PWN, Warszawa 2008.

Ustawa z dnia 12 grudnia 2013 r. o cudzoziemcach, DzU 2013, poz. 1650.

Wysieńska K., Nguyen, Serhij, czy Piotr? Pilotażowe badanie audytowe dyskryminacji cudzoziemców w rekrutacji, Fundacja Instytut Spraw Publicznych, Warszawa 2010.

Wysieńska K., Testy dyskryminacyjne - metoda i zastosowania, w: W poszukiwaniu nowych wzorów integracji cudzoziemców. Wybór tekstów polskiego forum integracyjnego, red. J. Segeš-Frelak, K. Grot, Fundacja Instytut Spraw Publicznych, Warszawa 2013.

Założenia polityki ludnościowej Polski 2006, Raport Rządowej Rady Ludnościowej, Warszawa 2006. 
Założenia polityki ludnościowej Polski 2013. Projekt, Rządowa Rada Ludnościowa, Warszawa 2013.

http://www.isp.org.pl/projekty,rozni, - ale-rowni-badania-nad-rownym-traktowaniemcudzoziemcow-w-polsce, $664 . \mathrm{html}$

http://udsc.gov.pl/statystyki/raporty-okresowe/zestawienia-roczne/

\section{Selected Aspects of Migration Policy in The Light of The Research on The Arab Diaspora in Poland}

This article presents the history and development of the (im) migration policy in the context of field research on the Arab Diaspora in Poland. Particular attention was paid to the issue how members of the Diaspora and examined Poles perceive the Polish migration policy in the aspect of the document titled "The Migration Policy of Poland - Current State and the Postulated Actions". Due to the fact that some of the comments and opinions of the respondents had a universal character applicable to all immigrants in Poland, not only to the explored community, this article presents specific innovative and practical solutions useful in forming a basis for migration policy.

Keywords: migration policy, Poland, Arab Diaspora, Arabs

\section{Les éléments sélectionnés de la politique migratoire en Pologne dans la lumière de recherche sur la diaspora arabe}

Cet article présente l'histoire et le développement de la politique migratoire en Pologne dans le contexte de l'enquête de terrain sur la diaspora arabe. Une attention particulière a été accordée à la question comment les membres de cette diaspora et les Polonais examinés perçoivent la politique migratoire polonaise dans le contexte du document intitulé "La politique migratoire de la Pologne - l'état actuel et les actions postulées". En raison du fait que certains commentaires et opinions des répondants avaient un caractère universel, applicable à tous les immigrants en Pologne, non seulement à ceux de la communauté arabe, cet article présente les solutions qui pourraient être utiles à la fomulation des fondations de la politique migratoire dans ce pays.

Mots-clés: la politique migratoire, la Pologne, la diaspora arabe, les Arabes 


\section{Избранные аспекты миграционной политики в контексте исследований арабской диаспоры в Польше}

В статье представлены история и развитие польской (им)миграционной политики в контексте исследований арабской диаспоры в Польше. Особое внимание уделяется вопросу, как воспринимается членами диаспоры и поляками миграционная политика Польши, отраженная в документе Польская миграционная политика - текущее состояние и постулируемые действия. В связи с тем, что некоторые из замечаний и мнений респондентов носят универсальный характер - относясь ко всем иммигрантам в Польше, а не только к исследуемому сообществу, - в статье представлены конкретные инновационные и практические решения, которые можно использовать при формировании основ миграционной политики.

Ключевые слова: миграционная политика, Польша, арабская диаспора, арабы 